Jurnal Ekonomi dan Industri

e-ISSN: 2656-3169

Volume 21, No. 1, Januari-April 2020

p-ISSN: 0853-5248

\title{
METODE CONTROL CHART DAN FISHBONE TERHADAP PRODUK POWER HOUSE PADA UNIT PENGOLAHAN SAMPAH TERPADU LINGKUNGAN HIDUP PROVINSI DKI JAKARTA
}

\author{
Huzair Tarmizi ${ }^{1)}$ \\ 1) Mahasiswa Program Studi FE UNKRIS \\ Siwi Nur Indriyani ${ }^{2)}$ \\ 2) Dosen Program Studi Manajemen FE UNKRIS \\ Alamat: Kampus UNKRIS, Jatiwaringin Jakarta Timur \\ Email : siwiindriyani76@gmail.com
}

\begin{abstract}
This Study aims to control the quality of power house production found in the Bantar Gebang Integrated Waste Management Unit (UPST). The Problem Faced is that there is still damage to the intercooler due to water entering the pipeline, so there is damage to the engine so that methane can not be produced into electricity. The method used is a statistical method and a quality control tool that is seven tools. The statiscal tools used in this study are : control charts and cause and effect diagram (fish bone).
\end{abstract}

Keywords: Qontrol chart and fishbone, power house

\section{PENDAHULUAN}

Sampah yang berasal dari aktivitas penduduk di perkotaan sangat besar jumlahnya dan diduga berpotensi sebagai sumber gas metana. Gas metana merupakan salah satu Gas Rumah Kaca (GRK) yang dapat menyebabkan efek rumah kaca, sebagai penyebab terjadinya pemanasan global (Global Warming). Saat ini terdapat kurang lebih 450 TPA di kota besar dengan sistem open dumping dan baru sebagian kecil yang dikembangkan menjadi controled landfil.

Potensi sampah yang dapat dihasilkan dari 45 kota besar di Indonesia mencapai 4 juta ton/tahun. Potensi gas metana yang bisa dihasilkan mencapai 11.390 ton $\mathrm{CH} 4$ / tahun atau setara dengan 239.199 ton CO2 / tahun, jumlah ini merupakan 64\% dari total emisi sampah berasal dari 10 kota besar, antara lain : Jakarta, Surabaya, Bandung,Medan, Semarang, Palembang, Makasar, Bekasi, Depok, dan Tanggerang.

Gambaran besarnya potensi GRK dari sampah ini, menuntut perubahan didalam pengelolaan sampah di Indonesia, oleh karena itu dalam Undang-Undang Nomor 18 Tahun 2008 tentang Pengelolaan Persampahan, menyatakan bahwa pengelolaan sampah diselenggarakan berdasarkan azas tanggung jawab, berkelanjutan, manfaat, keadilan, kesadaran, kebersamaan, keselamatan keamanan, dan nilai ekonomi, dengan tujuan meningkatkan kesehatan masyarakat dan kualitas lingkungan serta menjadikan sampah sebagai sumber daya. Kondisi ini akan lebih optimal bila ditunjang dengan pemilahan sampah di sumbernya dan di Tempat Pengelolaan Sampah Terpadu (TPST).

Saat ini sudah beberapa kota membangun atau memodifikasi TPA-nya dengan sistem Sanitary Landfil (SL). Gas yang dihasilkan dari SL dapat digunakan untuk pembangkit listrik, bahan bakar kendaraan, dan dapat dikonversi nilainya dalam perdagangan karbon internasional. 
Kualitas memegang peranan penting dalam suatu operasional pengelolahan Power house. Dalam operasional diperlukan kualitas yang baik dalam memproduksi power house agar tercipta hasil yang berkualitas dan sesuai dengan apa yang diharapkan.

Kualitas suatu produk bukan suatu yang serba kebetulan (occur by accident) (Prawirosentono, 2007). Kualitas dapat diartikan sebagai tingkat atau ukuran kesesuaian suatu produk dengan pemakainya. dalam arti sempit kualitas diartikan sebagai tingkat kesesuaian produk dengan standar yang telah ditetapkan (Alisjahbana, 2005). Jadi kualitas yang baik akan dihasilkan dari proses yang baik dan sesuai dengan standar kualitas yang telah ditentukan.

Menurut Gasperz (1998), kualitas didefinisikan sebagai konsistensi peningkatan atau perbaikan dan penurunan variasi karakteristik dari suatu produk (barang atau jasa) yang dihasilkan agar memenuhi kebutuhan yang telah dispesifikasikan guna meningkatkan kepuasan pelanggan.

Menurut Crosby dalam buku pertamanya "Quality is Free" yang mendapatkan perhatian sangat besar pada waktu itu (1979) menyatakan, bahwa kualitas adalah "conformance to requirement", yaitu sesuai dengan yang disyaratkan atau distandarkan. Suatu produk memiliki kualitas apabila sesuai dengan standar kualitas yang telah ditentukan. Deming (1982) menyatakan, bahwa kualitas adalah kesesuaian dengan kebutuhan pasar. Menurut Prawirosentono (2007), pengertian kualitas suatu produk adalah "Keadaan fisik, fungsi, dan sifat suatu produk bersangkutan yang dapat memenuhi selera dan kebutuhan konsumen dengan memuaskan sesuai nilai uang yang telah dikeluarkan".

Jakarta adalah salah satu wilayah yang memiliki pengelolaan sampah terbesar dengan jumlah sampah 7000 ton perhari yang masuk ke unit pengelola sampah terpadu (UPST) Bantar Gebang.

Tabel 1: Total produksi Tahunan 2019

\begin{tabular}{|c|c|c|c|c|c|}
\hline \multirow[b]{2}{*}{$\begin{array}{c}\text { Bulan } \\
\text { Produksi }\end{array}$} & \multirow[b]{2}{*}{$\underset{\text { Produksi }}{\text { Jumlah }}$} & \multicolumn{2}{|c|}{ Jenis Cacat } & \multirow[b]{2}{*}{$\underset{\text { Kecacatan }}{\text { Jumlah }}$} & \multirow[b]{2}{*}{$\begin{array}{c}\text { Persentase } \\
(\%)\end{array}$} \\
\hline & & $\begin{array}{c}\text { Trouble } \\
\text { Mesin }\end{array}$ & $\begin{array}{c}\text { Kebocoran } \\
\text { Jalur } \\
\text { Perpipaan }\end{array}$ & & \\
\hline Januari & 26400 & 120 & 30 & 150 & 0.6 \\
\hline Februari & 22000 & 178 & 22 & 200 & 0.9 \\
\hline Maret & 23100 & 90 & 23 & 113 & 0.5 \\
\hline April & 21500 & 180 & 79 & 259 & 1.2 \\
\hline Mei & 25300 & 90 & 19 & 109 & 0.4 \\
\hline Juni & 26400 & 125 & 15 & 140 & 0.5 \\
\hline Juli & 25000 & 60 & 25 & 85 & 0.3 \\
\hline Agustus & 26400 & 99 & 20 & 119 & 0.5 \\
\hline September & 23100 & 67 & 15 & 82 & 0.4 \\
\hline Oktober & 25100 & 88 & 15 & 103 & 0.4 \\
\hline Nopember & 22100 & 75 & 27 & 102 & 0.5 \\
\hline Desember & 22440 & 87 & 18 & 105 & 0.5 \\
\hline Total & 288840 & 1259 & 308 & 1567 & 0.5 \\
\hline Rata-Rata & 24070 & 105 & 26 & 131 & 0.5 \\
\hline $\begin{array}{l}* I: \text { Merk M } \\
\text { II: Merk Ino }\end{array}$ & $\begin{array}{l}\text { lflex } \\
\text { ex }\end{array}$ & & & & \\
\hline
\end{tabular}

Sumber : Data Internal Perusahaan 


\section{LANDASAN TEORI}

\section{Tujuan Pengendalian kualitas}

Tujuan dari pengendalian kualitas adalah untuk mengawasi tingkat produksi melalui banyak tahapan produksi.Tujuan dari pengendalian kualitas adalah untuk mengetahui samapai sejauh mana proses dan hasil produk (jasa) yang dibuat sesuai dengan standar yang ditetapkan perusahaan. Selain hal tersebut, pengawasan kualitas adalah produk akhir mempunyai spesifikasi sesuai dengan standar kualitas yang telah ditetapkan agar biaya desain produk, biaya inspeksi dan biaya proses produksi dapat berjalan secara efisien.

Montgomery, alih bahasa Zanzawi (1995), tujuan dari pengendalian kualitas statistik adalah menyidik dengan cepat sebab-sebab terduga atau pergeseran proses sedemikian hingga penyelidikan terhadap proses itu dan tindakan pembetulan dapat dilakukan sebelum terlalu banyak unit yang tidak sesuai produksi. Sehingga secara umum tujuan utama pengendalian kualitas adalah pengawasan dan penyelidikan sebab-sebab terduga suatu proses agar produk tetap sesuai dengan standar kualitas yang ditetapkan.

\section{Pengendalian Kualitas Produk}

Peranan pengendalian kualitas produk menjadi bertambah besar dan penting dengan adanya perkembangan selera akibat peradaban manusia yang berubah. Perubahan selera tersebut mendorong konsumen untuk selalu mencari barang yang nilai gunanya lebih sempurna dan baik.

Kualitas suatu produk dengan proses produksi sangat erat kaitannya. suatu produk dibuat melalui proses pengolahan dari bahan baku menjadi barang setengah jadi dan akhirnya menjadi barang jadi (finished goods) berdasarkan kualitas yang diciptakan. Kualitas suatu produk berkaitan dengan bentuk, warna, dan dapat pula dikaitkan dengan seni, karena kualitas selalu dikaitkan dengan memenuhi selera konsumen. Konsumen bersedia membayar dengan harga mahal, asalkan mereka memperoleh kepuasan. Artinya mereka bersedia membeli suatu barang dengan harga yang masuk akal, tetapi kualitas baragnnya baik.

Kualitas suatu produk adalah keadaan fisik, fungsi, dan sifat suatu produk bersangkutan yang dapat memenuhi selera dan kebutuhan konsumen dengan memuaskan sesuai nilai uang yang telah dikeluarkan.

Pengendalian kualitas merupakan kegiatan terpadu mulai dari produk standar mutu bahan, standar proses produksi, barang setengah jadi, barang jadi, sampai standar pengiriman produk ke konsumen, agar barang atau jasa yang diproduksi sesuai dengan kualitas yang direncanakan (pemenuhan spesifikasi kebutuhan).

Pengendalian kualitas dapat dilakukan pada produk yang dihasilkan, atau dikenal dengan rencana penerimaan sampel produk (Acceptance sampling). merupakan proses evaluasi bagian produk dan seluruh produk yang dihasilkan untuk menerima seluruh produk yang dihasilkan tersebut. Jadi pengendalian kualitas suatu produk merupakan pekerjaan yang kompleks karena menyangkut berbagai tugas yang berkaitan dengan proses pembuatan suatu produk.

\section{Pengendalian Kualitas Statistik}

Batasan teknik pengendalian kualitas produksi adalah pengendalian kualitas produksi secara statistik. Pengendalian kualitas statistik (statistical quality control) secara garis besar digolongkan menjadi dua, yakni pengendalian proses statistik (statistical process control) atau yang sering disebut dengan control chart dan rencana penerimaan sampel produk atau yang sering dikenal dengan acceptance sampling. 
Pengendalian kualitas statistik (statistical quality control) merupakan teknik penyelesaian masalah yang digunakan sebagai pemonitor, pengendali, penganalisis, pengelola, dan memperbaiki proses menggunakan metode-metode statistik. Pengendalian proses satistik merupakan penerapan metode-metode statistik untuk pengukuran dan analisis variasi proses. Dengan pengendalian proses statistik maka dapat dilakukan analisis dan meminimalkan penyimpangan atau kesalahan, mengkuantifikasikan kemampuan proses dan membuat hubungan antara konsep dan teknik yang ada untuk mengadakan perbaikan proses. Keberhasilan dalam pengendalian proses statistik sangat dipengaruhi oleh tiga faktor, yakni sistem pengukuran, sistem pelatihan yang tepat, dan komitmen manajemen.

Kontrol kualitas secara statistik yang diingikan adalah yang memenuhi permintaan konsumen. Permintaan konsumen yang dimaksud adalah akhir kegunaan suatu produk dan harga jual suatu produk. Lebih lanjut hal ini dijabarkan dalam bentuk spesifikasi ukuran, ciri-ciri operasi, ongkos produk, syarat produksi untuk menghasilkan produk yang dikehendaki.

\section{Teknik Kontrol Kualitas Statistik}

Pada tahun 1924, Shewhart dari Bell Telephone Laboratories mengembangkan gagasan grafik pengendalian. Akan tetapi, baru pada Perang Dunia II penggunaan grafik pengendalian banyak dipakai. Hal ini di sebabkan karena pentingnya mempertahankan kualitas dalam proses produksi. Pada tahun 1950-an dan 1960-an, pengembangan pengendalian kualitas telah berkembang luas dan berhasil di gunakan di negara jepang berkat usaha keras dari Deming, yang bekerja sebagai konsultan di jepang setelah Perang Dunia II. Pengendalian kualitas statistik telah menjadi ramuan yang penting dalam memacu perkembangan industri dan ekonomi.

Pengendalian kualitas adalah kombinasi semua alat dan teknik yang digunakan untuk mengontrol kualitas suatu produk dengan biaya seekonomis mungkin untuk memenuhi syarat pemesan. Dalam mengendalikan proses kita berusaha menyelidiki dengan cepat bila terjadi gangguan proses dan tindakan pembetulan dapat segera dilakukan sebelum terlalu banyak unit yang tidak sesuai dengan produksi.

Faktor-faktor yang berpengaruhi dalam pengendalian kualitas adalah sebagai berikut: 1). Dari segi operator: keterampilan dan keahlian dari manusia yang menangani produksi. 2). Dari segi bahan baku: bahan baku yang dipasok oleh penjual. 3). Dari segi mesin: jenis mesin dan elemen-elemen mesin yang digunakan dalam proses produksi.

\section{Metode Control Chart}

Merupakan sebuah grafik yang memberikan gambaran tentang perilaku sebuah proses. Diagram ini digunakan untuk memhami apakah sebuah proses manufacturing atau proses bisnis berjalan dalam kondisi yang terkontrol atau tidak. Sebuah proses yang cukup stabil, tetapi berjalan di luar batas yang diharapkan harus diperbaiki untuk menemukan akar penyebabnya untuk mendapatkan hasil perbaikan yang fundamental.

\section{Metode Diagram Sebab-Akibat}

Menurut Heizer dan Render, diagram ini disebut juga diagram tulang ikan (fishbone chart) dan berguna untuk memperlihatkan faktor-faktor utama yang berpengaruh pada kualiatas dan mempunyai akibat pada masalah yang kita pelajari.

Diagram ini berguna untuk menganalisi dan menemukan faktor-faktor yang berpengaruh secara signifikan di dalam menemukan karakteristik kualitas output kerja dan berguna untuk mencari penyebab-penyebab yang sesungguhnya dari suatu masalah. 
Diagram ini disebut juga Ishikawa Diagram karena diagram ini diperkenalkan oleh Ishikawa pada tahun 1943. Diagram ini terdiri dari sebuah panah horizontal yang pajang dengan deskripsi masalah. Penyebab-penyebab masalah yang digambarkan dengn garis radial dan garis panah yang menunjukan masalah.

\section{Grafik Pengendali Kulitas Proses Statistik}

Teori umum grafik pengendali ini pertama kali diperkenalkan oleh Shewhart dari Bell Telephone Laboratories Amerika Serikat pada tahun 1942, dan grafik pengendalian yang dikembangkan menurut asas- asas ini kerap kali dinamakan Grafik Pengendali Shewhart. Sebuah grafik pengendalian memiliki sebuah garis tengah dan batas-batas pengendali, baik pengendalian atas maupun bawah. Grafik di bawa ini memuat garis tengah yang merupakan nilai rata-rata karakteristik kualitas yang berkaitan dengan keadaan terkontrol (yakni, hanya sebab-sebab tidak terduga yang ada), sedangkan dua garis mendatar merupakan batas pengendali atas dan batas pengendalian bawah, batas-batas pengendalian ini dipilih sedemikian hingga apabila proses terkendali, hampir semua titiktitik sampel akan jatuh diantara kedua garis itu. Selama titik-titik terletak di dalam batasbatas pengendalian, maka proses dianggap dalam keadaan terkendali. Ini berarti proses berlangsung atau beroperasi di bawah penyebab wajar sebagaimana diharapkan atau berjalan karena penyebab sistem tetap yang sifatnya probabilistik, dan tidak perlu tindakan apapun. Tetapi, apabila satu titik yang terletak di luar batas pengendali di artikan sebagai fakta bahwa proses tidak terkendali, dan diperlukan tindakan penyelidikan dan perbaikan untuk mendapatkan terjadinya sebab tidak terduga itu.

Grafik pengendalian adalah alat untuk menggambarkan dengan cara yang tepat apa yang dimaksudkan dengan pengendali statistik, dimana bentuk grafik ini sangat sederhana yang terdiri atas tiga buah garis mendatar dan sejajar. Grafik pengendali sumbu datar melukiskan nomor sampel yang diteliti dari sampel kesatu, kedua, dan seterusnya. Sumbu tegak menyatakan karakteristik yang sedang diteliti, misalnya rata-rata, presentase dan sebagainya. Seperti yang digambarkan pada grafik 1 di bawah ini :

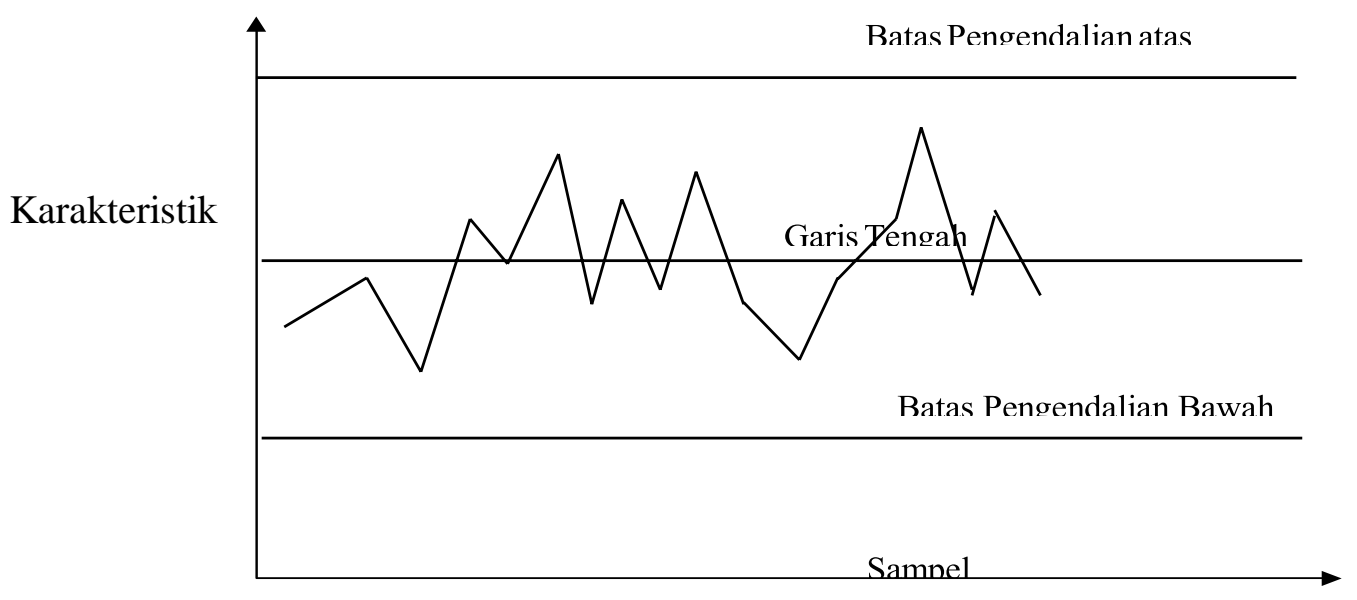

1234567891011121314151617181920

\section{Gambar 1 Grafik Pengendalian}

Bentuk dasar grafik pengendalian diatas merupakan suatu karakteristik kualitas. Grafik pengendalian ini terdiri dari: a). Sumbu tegak menyatakan karakteristik kualitas yang akan diteliti. b). Sumbu mendatar menyatakan jumlah sampel. c). Sumbu tengah 
melukiskan nilai baku yang menjadi pangkal perhitungan dari hasil-hasil pengamatan tiap sampel. d). Batas bawah yang sejajar dengan garis tengah dinamakan Lower Conttrol Limit (LCL) atau batas kontrol bawah, ini merupakan data pada batas kontrol bawah yang dihitung dari nilai baku. e). Batas atas yang sejajar dengan garis tengah dinamakan Upper Control Limit (UCL) atau batas kontrol atas, ini merupakan data pada batas kontrol atas yang dihitung dari nilai baku. Grafik pengendian diatas meskipun terlihat bahwah semua titik-titik terletak di dalam batas pengendali, namun apabila titik-titik itu terjadi karena sebab-sebab tidak terduga secara sistematik atau tidak random, maka ini merupakan petunjuk bahwa proses tidak terkendali. Sehingga, kegunaan grafik pengendali adalah untuk membatasi toleransi penyimpangan (variasi) yang masih dapat diterima, baik karena akibat kelemahan tenaga kerja (operator), mesin yang di pasang tidak wajar dan bahan baku yang kurang baik.

\section{Bagan Kendali (Sebab-sebab terduga dan tak terduga variabilitas kualitas)}

Variabilitas dasar atau "gangguan dasar" adalah pengaruh kumulatif dari banyak sebab-sebab kecil, yang pada dasarnya tidak terkendali. Dalam kerangka pengendalian kualitas statistik, variabel dasar ini dinamakan "sistem stabil sebab- sebab tidak terduga". Suatu proses yang bekerja hanya dengan adanya variasi sebab-sebab tidak terduga dikatakan ada dalam pengendalian statistik.

Macam-macam variabilitas lain kadang-kadang timbul dalam hasil suatu proses. Variabilitas ini dalam karakteristik kualitas kunci biasanya timbul dari tiga sumber yaitu mesin yang dipasang tidak wajar, tenaga kerja (operator) dan bahan baku yang cacat. Variabilitas seperti itu umumnya besar apabila dibandingkan dengan gangguan dasar dan biasanya merupakan tingkat yang tidak dapat diterima dalam proses, maka harus segera dicari ketidakwajaran tersebut untuk diambil langkah perbaikan. Sumber-sumber variabilitas ini dinamakan "sebab-sebab terduga". Suatu proses yang bekerja dengan adanya sebab-sebab terduga dikatakan tidak terkendali.

\section{Pengendali Proporsi Kesalahan ( $p$-Chart)}

Pengendali proporsi kesalahan digunakan untuk mengukur ketidaksesuaian (penyimpangan atau sering disebut cacat) dari item-item dalam kelompok yang sedang inspeksi. Dengan demikian pengendali $\mathrm{p}$ digunakan untuk mengendalikan proporsi dari item-item yang tidak memenuhi syarat spesifikasi kualitas atau proporsi dari produk cacat yang dihasilkan dalam suatu proses. Proporsi yang tidak memenuhi syarat didefinisikan sebagai rasio banyaknya item yang tidak memenuhi syarat dalam suatu kelompok terhadap total banyaknya item dalam kelompok itu. Item-item itu dapat mempunyai beberapa karakteristik kualitas yang diperiksa atau diuji secara simultan oleh pemeriksa. Jika itemitem itu tidak memenuhi standar pada satu atau lebih karakteristik kualitas yang diperiksa, maka item-item itu digolongkan sebagai tidak memenuhi syarat spesifikasi atau cacat. Proporsi sering diungkapkan dalam bentuk decimal. Apabila ditemukan nilai negatif dalam perhitungan batas pengendalian bawah $(B P B)$, maka ditetapkan sama dengan nol. Jadi apabila $B P B<0$, maka ditetapkan $\mathrm{BPB}=0$. Untuk banyaknya sampel yang bervariasi grafik pengndali $\mathrm{p}$ mempunyai tiga beberapa pilihan model, yaitu menggunakan grafik pengendalian model harian atau individu, grafik pengendali model rata-rata dan grafik pengendali dengan model yang dibuat menurut urutan banyaknya sampel berdasarkan pertimbangan perusahaan. 


\section{METODE PENELITIAN}

Dalam penelitian ini yang menjadi objek dalam pengambilan data adalah Unit Pengelola Sampah Terpadu (UPST) Data yang diambil adalah data periode Januari Desember 2019. Metode yang akan dipakai untuk mengatasi masalah yang ada di Unit Pengelola Sampah terpadu (UPST) adalah menggunakan dua metode statistik yang dapat dijelaskan sebagai berikut : 1). Membuat Control Chart yaitu untuk memonitor dan mengevaluasi apakah proses berada dalam pengendalian kualitas secara statistika atau tidak sehingga dapat memecahkan masalah dan menghasilkan perbaikan kualitas. 2). Membuat Diagram Sebab-akibat yaitu untuk mencari penyebab terjadinya masalah yang ada atau kecacatan produksi.

\section{HASIL PENELITIAN DAN PEMBAHASAN}

\section{Control Chart}

Dengan menggunakan data yang diperoleh dari Unit Pengelola Sampah Terpadu (UPST) pada tahun 2019 dengan jumlah sebanyak 42.860 unit ditemukan kerusakan selama tahun 2019 sebanyak 2675 unit. Pengukuran dilakukan dengan control chart kualitas secara statistik. Dari data-data tersebut dapat dibuat peta kendali dengan langkah sebagai berikut : a). Menghitung mean atau gris tengah atau (UCL) atau rata-rata produk akhir, b). Menghitung persentase kerusakan. c). Menghitung batas kendali atas atau Upper Control Limit (UCL). d). Menghitung batas kendali bawah atau Lower Control Limit (LCL)

Tabel 2: Perhitungan Batas Kendali Bagian pengepakan Periode tahun 2019

\begin{tabular}{|c|c|c|c|c|c|c|c|}
\hline \multicolumn{2}{|c|}{ Bulan Produksi } & $\begin{array}{c}\text { Jumlah Produksi } \\
\text { (Unit) }\end{array}$ & \begin{tabular}{|c|} 
Jumlah Cacat \\
Produksi
\end{tabular} & $\begin{array}{c}\text { Proposi Cacat } \\
\text { Produksi }(p)\end{array}$ & $C L$ & UCL & LCL \\
\hline \multirow{2}{*}{ Januari } & $\mathrm{I}$ & 2389 & 154 & 6,4 & 0,062413 & 0,091455 & 0,033371 \\
\hline & II & 1101 & 110 & 10,0 & 0,062413 & 0,100011 & 0,024815 \\
\hline \multirow{2}{*}{ Februari } & $\mathrm{I}$ & 2201 & 102 & 4,6 & 0,062413 & 0,092259 & 0,032567 \\
\hline & $\|$ & 1619 & 97 & 6,0 & 0,062413 & 0,095476 & 0,029350 \\
\hline \multirow{2}{*}{ Maret } & $\mathrm{I}$ & 2570 & 115 & 4,5 & 0,062413 & 0,090756 & 0,034070 \\
\hline & $\|$ & 1320 & 103 & 7,8 & 0,062413 & 0,097805 & 0,027021 \\
\hline \multirow{2}{*}{ April } & $\mathrm{I}$ & 2409 & 107 & 4,4 & 0,062413 & 0,091374 & 0,033452 \\
\hline & II & 1151 & 108 & 9,4 & 0,062413 & 0,099459 & 0,025367 \\
\hline \multirow{2}{*}{ Mei } & $\mathrm{I}$ & 2670 & 115 & 4,3 & 0,062413 & 0,090398 & 0,034428 \\
\hline & II & 1280 & 98 & 7,7 & 0,062413 & 0,098170 & 0,026656 \\
\hline \multirow{2}{*}{ Juni } & $\mathrm{I}$ & 875 & 111 & 12,7 & 0,062413 & 0,103004 & 0,021822 \\
\hline & II & 575 & 102 & 17,7 & 0,062413 & 0,109101 & 0,015725 \\
\hline \multirow{2}{*}{ Juli } & $\mathrm{I}$ & 2789 & 120 & 4,3 & 0,062413 & 0,089994 & 0,034832 \\
\hline & II & 1211 & 104 & 8,6 & 0,062413 & 0,098837 & 0,025989 \\
\hline \multirow{2}{*}{ Agustus } & $\mathrm{I}$ & 2657 & 113 & 4,3 & 0,062413 & 0,090444 & 0,034382 \\
\hline & II & 1603 & 107 & 6,7 & 0,062413 & 0,095586 & 0,029240 \\
\hline \multirow{2}{*}{ September } & 1 & 2789 & 119 & 4,3 & 0,062413 & 0,089994 & 0,034832 \\
\hline & II & 941 & 106 & 11,3 & 0,062413 & 0,102032 & 0,022794 \\
\hline \multirow{2}{*}{ Oktober } & $\mathrm{I}$ & 2340 & 127 & 5,4 & 0,062413 & 0,091656 & 0,033170 \\
\hline & II & 1350 & 101 & 7,5 & 0,062413 & 0,097541 & 0,027285 \\
\hline \multirow{2}{*}{ November } & $\mathrm{I}$ & 2980 & 129 & 4,3 & 0,062413 & 0,089392 & 0,035434 \\
\hline & II & 1150 & 117 & 10,2 & 0,062413 & 0,099469 & 0,025357 \\
\hline \multirow{2}{*}{ Desember } & $\mathrm{I}$ & 1529 & 113 & 7,4 & 0,062413 & 0,096113 & 0,028713 \\
\hline & II & 1361 & 97 & 7,1 & 0,062413 & 0,097446 & 0,027380 \\
\hline Total & & 42860 & 2675 & 6,2 & & & \\
\hline Rata - Rata & & 3572 & 223 & 6,2 & & & \\
\hline
\end{tabular}


Berdasarkan Tabel 2 sampel yang digunakan adalah sebanyak 24. Dari gambar tersebut dapat diketahui bahwa ada satu titik yang berada di luar batas kendali bawah yaitu sampel 12, dua titik berada di luar batas kendali atas yaitu sampel 11 dan 18. Dari peta kendali tersebut juga tampak bahwa garis pusat sebesar 0,062413, UCL atau BPA sebesar 0,109101 dan LCL atau BPB sebesar 0,015725

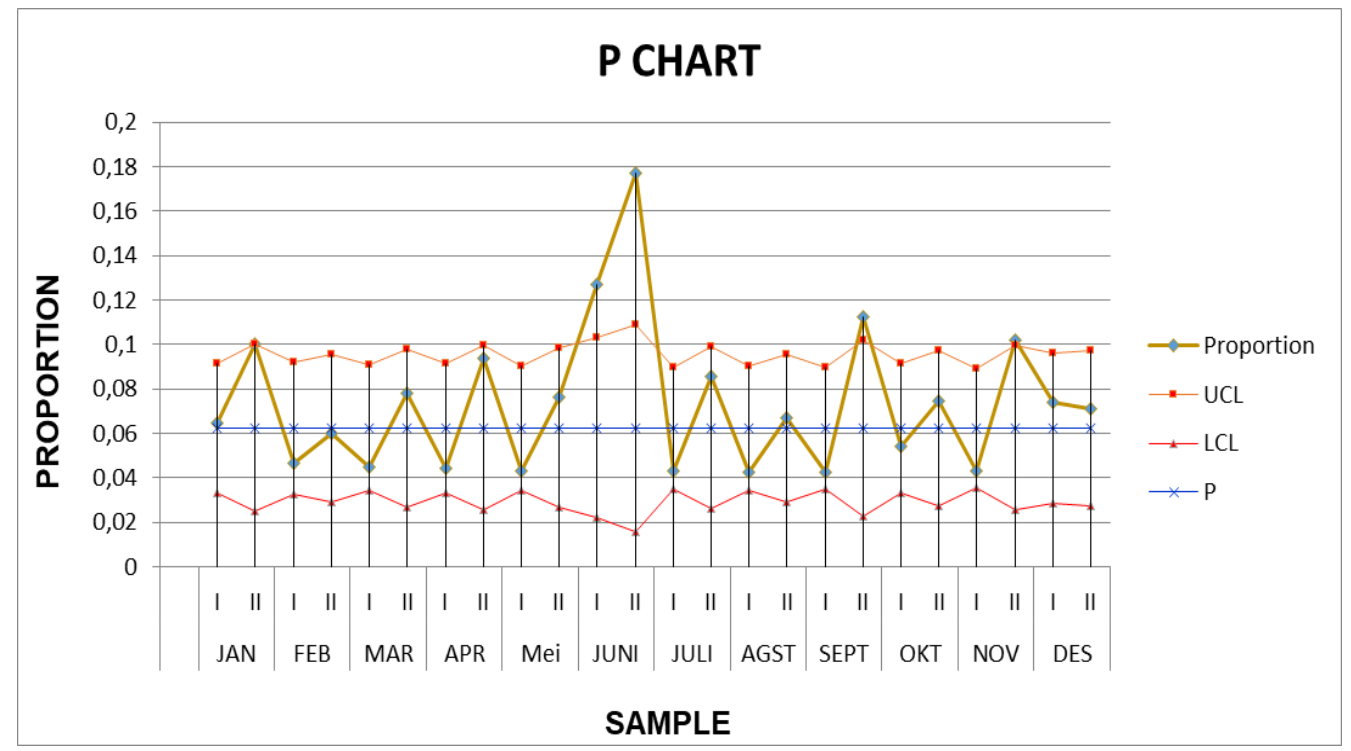

Gambar 1: Peta Kendali Proporsi Cacat Produksi Bagian Intercooler Tahun 2019

Berdasarkan gambar 1 sampel yang digunakan adalah sebanyak 24. Dari gambar 2 tersebut dapat diketahui bahwa ada satu titik yang berada di luar batas kendali bawah yaitu sampel 12 dan dua titik berada di luar batas kendali atas yaitu sampel 11 dan 18. Dari peta kendali tersebut juga tampak bahwa garis pusat sebesar 0,062413, UCL atau BPA sebesar 0,109101 dan LCL atau BPB sebesar 0,015725

Dari hasil peta kendali yang diperoleh pula dapat dilihat proses produksi di bagian power house masih ada yang berada diluar batas kendali.

\section{Diagram Sebab-akibat}

Setelah diagram sebab akibat yang utuh dibuat maka dapat dilihat bahwa penyebab kecacatan yang paling dominan di bagian Intercooler. Intercooler dalam produksi power house mempunyai peranan penting karena semua aktifitas dilakukan melalu proses intercoler. 


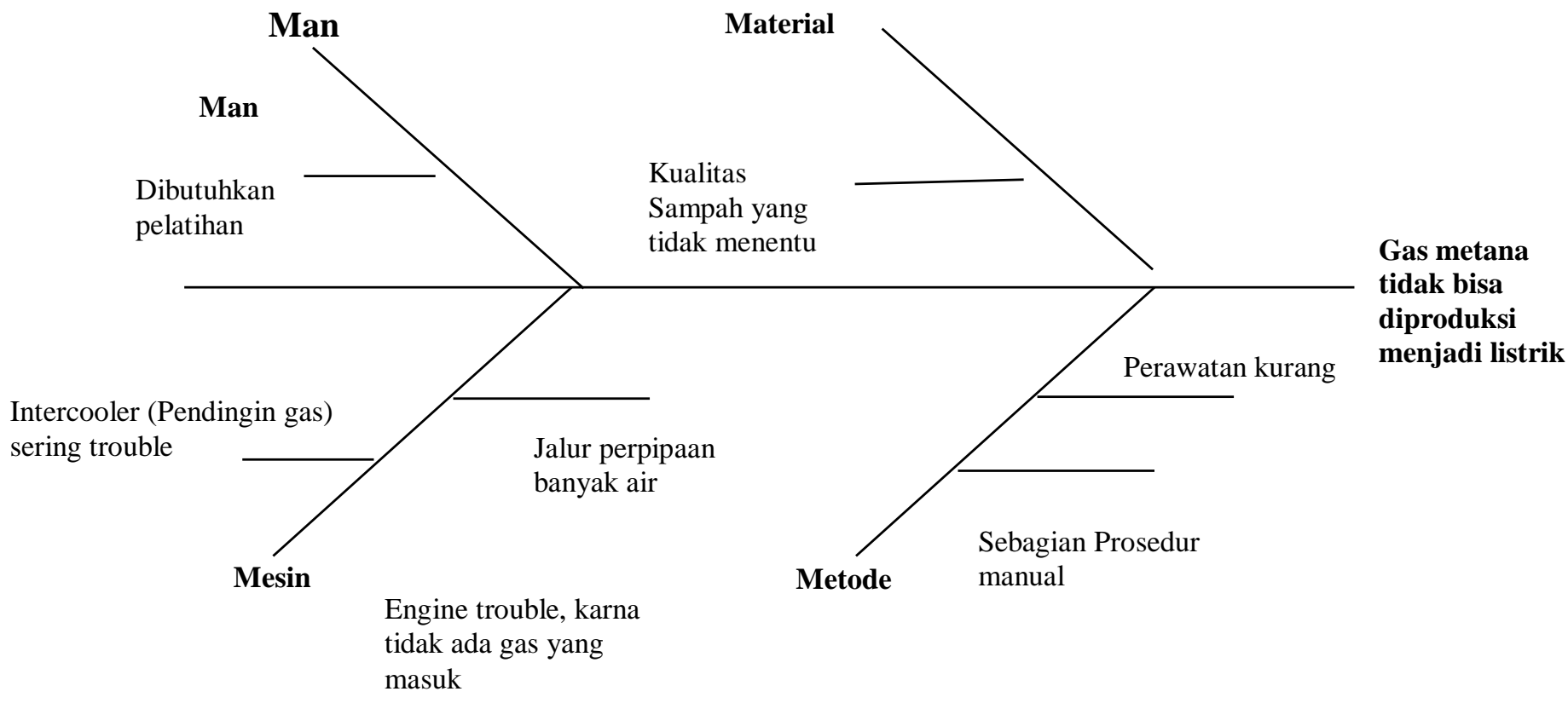

\section{Gambar 2: Diagram Sebab Akibat Bagian Pencampuran dan Pengepakan Sumber: Wawancara dan observasi}

\section{KESIMPULAN DAN SARAN}

Jenis cacat produksi produksi power house di Unit Pengelola Sampah terpadu (UPST) yaitu disebabkan karena intercooler teruble sebanyak 2675 kali dalam 1 tahun.

\section{Control Chart}

Penggunaan alat bantu statistik dengan peta kendali $\mathrm{p}$ mengidentifikasi bahwa ternyata banyak kualitas produk yang berada di luar batas kendali yang seharusnya. Hal tersebut seperti ditunjukkan pada grafik kontrol yang memperlihatkan bahwa titik berfluktuasi sangat tinggi dan tidak beraturan. Hal ini menyimpulkan bahwa proses produksi di bagian intercooler berada dalam keadaan tidak terkendali atau masih banyak mengalami trouble.

\section{Diagram Sebab-Akibat}

Hasil dari tahap ini adalah berasal dari wawancara dengan korlap produksi dan observasi yang terkait dengan proses produksi. Dari diagram sebab-akibat ditemukan penyebab kecacatan dalam proses produksinya ada 4 yaitu manusia, mesin, material dan metode. Penyebab kecacatan yang paling banyak adalah berasal dari mesin.

Berdasarkan analisis atau penelitian yang telah dilakukan, Maka terdapat beberapa rekomendasi yang dapat diberikan kepada unit pengelolaan sampah terpadu (UPST) dengan tujuan mengendalikan proses produksinya agar menjadi lebih baik. Berikut adalah beberapa rekomendasinya: 1). Lebih memperketat pengawasan saat proses produksi berlangsung dan membuat standar kerja dalam lingkungan kerja sehingga pekerja mengerti dan menjalankan prosedur kerja yang dibuat. 2). Memberikan tugas pada bagian Quality Control untuk memeriksa jalur perpipaan saat operasional berlangsung. 3). Melakukan perawatan peralatan setiap minggu agar ada tindakan pencegahan kerusakan atau melakukan maintenance. 


\section{DAFTAR PUSTAKA}

Alisjahbana, Juita. 2005. "Evaluasi Pengendalian Kualitas Total Produk Pakaian Wanita Pada Perusahaan Konveksi." Jurnal Ventura, Vol. 8, No. 1, April 2005.

Ariani, Dorothea Wahyu. 2004. Pengendalian Kualitas Statistik. Yogyakarta. Penerbit: Andi

Assauri, Sofjan. 1998. Manajemen Operasi Dan Produksi. Jakarta : LP FE UI Besterfield,

Dale H., Quality Control, $4^{\text {th }}$ edition, Prentice Hall International., New Jersey 1994.

Crosby, Phillip B. 2003. Quality is Free. Penerbit: Penguin

Deming, W. Edwards. 2005. Total Quality Management. Jakarta. Penerbit: Rineka Cipta

Dwiwinarno, Titop. 2009. "Evaluasi Pengendalian Kualitas Pada Bagian Produksi." www.google.com. Diunduh tanggal 21 Maret 2012.

Gasperz, Vincent. 2005. Total Quality Management. Jakarta. Penerbit: PT. Gramedia Pustaka Utama.

Hatani, La. 2008. "Manajemen Pengendalian Mutu Produksi Roti Melalui Pendekatan Statistical Quality Control (SQC)." Diunduh 12 Maret 2012, dari www.google.com/Jurusan Manajemen FE Unhalu.

Heizer, Jay and Barry Render. 2006. Operations Management (Manajemen Operasi). Jakarta : Salemba Empat.

Juran, Joseph. 2005. Total Quality Management Jakarta. Penerbit: Rineka Cipta

Kholil, Muhammad dan A. Cahyono. 2006. "Usulan Perbaikan Kualitas Dengan Metode SPC Untuk Mengurangi Cacat Bending Part Scale PF Pada Proses Injection Pada Produk Plastic Departement PT. Indonesia Epson Industry." Buletin Penelitian No. 10 Tahun 2006.

Prawirosentono, Suyadi. 2007. Filosofi Baru Tentang Manajemen Mutu Terpadu Abad 21 "Kiat Membangun Bisnis Kompetitif". Jakarta: Bumi Aksara.

Mitra, Amitava. 1993. Fundamentals of Quality and Improvement. Penerbit Mac Millan

Mongomery, Douglas C. 2001. Introduction to Statistical Quality Control. $4^{\text {th }}$ Edition. New York : John Wiley \& Sons, Inc.

Nasution, M. N. 2005. Manajemen Mutu Terpadu. Bogor : Gahlia Indonesia.

Rath \& Strong. 2005. Six sigma advance Tools Pocket Guide. Yogyakarta. Penerbit: Andi

Sarin, Rakesh K. dan Buffa, Elwood S. 1999. Manajemen Operasi \& Produksi Modern. Penerbit: Binarupa Aksara

Ramsey, Patricia P. and Levine, David M. 1994 Business for Quality and Productivity Pretices Hall International. Penerbit International Encyclopedia

Richard B. Chase, Nicholas J. Aquilano and F. Robert Jacobs. 2001. Operations Management For Competitive Advantage. 9th Edition. New York : Mc Graw-Hill Companies. 